\title{
Competitive authoritarianism in Africa revisited
}

\author{
Matthijs Bogaards · Sebastian Elischer
}

Published online: 1 October 2015

(C) Springer Fachmedien Wiesbaden 2015

\begin{abstract}
Competitive authoritarianism has emerged as a major concept in the study of political regimes. The introduction of this special issue revisits Levitsky and Way's seminal study Competitive Authoritarianism: Hybrid Regimes After the Cold War. Although Africa is the world region with the highest absolute number of competitive authoritarian regimes, political scientists working on Africa have rarely engaged with Levitsky and Way's modern classic. In this introduction, we summarize their arguments, outline the empirical findings for Africa, and review the critiques. In doing so we provide the background for the contributions to this special issue.
\end{abstract}

Keywords Comparative politics $\cdot$ Political regimes $\cdot$ Autocratization · Competitive authoritarianism $\cdot$ Africa

The third wave of democratization and the end of the Cold War made multiparty elections a common phenomenon across the globe. ${ }^{1}$ The initial euphoria that accompanied the political changes of the early 1990s soon gave way to the realization that elections do not automatically result in fully democratized regimes (Schedler 1998;

\footnotetext{
${ }^{1}$ The authors would like to thank the Fritz Thyssen Foundation and the Centre for the Study of Democracy at the Leuphana University Lüneburg for their generous funding of an author workshop in Lüneburg in November 2013.
}

Prof. M. Bogaards $(\bowtie)$

Department of Political Studies, University of Cape Town,

Cape Town, South Africa

e-mail: Visbogaards@ceu.edu

Asst. Prof. S. Elischer

Department of Political Science, University of Florida,

Gainesville, USA

e-mail: selischer@ufl.edu 
Carothers 2002; O'Donnell and Schmitter 2013; Schedler 2013; for Africa see van de Walle 2002). In many countries the democratic transitions of the third wave saw the establishment of hybrid regimes, which share a mixture of democratic and autocratic features (Diamond 2002; Karl 1995; Bogaards 2009). Levitsky and Way are the first scholars to engage systematically, and in a global manner, with the analysis of one particular type of hybrid regime: competitive authoritarianism. They first introduced the concept of "competitive authoritarianism" in a 2002 article in the Journal of Democracy. According to the Social Science Citation Index, their article had been cited 402 times when this issue went to press. Levitsky and Way's book Competitive Authoritarianism: Hybrid Regimes After the Cold War (2010) has been very well received. Praise has been unanimous, with epithets such as "game-changing" (Bejarano 2011, p. 715), "benchmark" (Slater 2011, p. 388), "classic" (Weidmann 2011, p. 818), and "new classic" (Seeberg 2011, p. 143; Kubik 2011, p. 664)

Although 14 of Levitsky and Way's 35 cases of competitive authoritarianism are located in Africa, and Africa is the continent with the highest absolute number of competitive authoritarian regimes today, scholarship on Africa has failed to engage with the concept and the theory. ${ }^{2}$ As far as we know, their book was not reviewed by any journals specialized in African politics. Apart from Matti's (2010) case study of competitive authoritarianism in the Democratic Republic of Congo (DRC), Africanists have not worked systematically with the concept or the theory of competitive authoritarianism. That is regrettable because, as the contributions to this special issue show, Levitsky and Way's analysis has much to offer students of Africa's many hybrid regimes.

This introduction revisits comparative authoritarianism in Sub-Saharan and North Africa by summarizing Levitsky and Way's argument and its application to the continent, reviewing the critiques, and by outlining how the contributors to this special issue have engaged the theory, the concept, and the empirical evidence, taking the study of regime trajectories in Africa forward. ${ }^{3}$

\section{Democracy, competitive authoritarianism, and autocracy}

Levitsky and Way distinguish between three regime types: democracies, competitive autocracies, and full autocracies. Their definition of democracy starts with Dahl (1971, pp. 5-6), but then adds the existence of a reasonably level playing field to free, fair, and competitive elections, full adult suffrage, broad protection of civil liberties, and absence of non-elected "tutelary" powers. Only if all of these conditions are met are countries classified as democracies.

\footnotetext{
${ }^{2}$ More countries would have qualified if Levitsky and Way (2010) had not excluded electoral autocracies where the military is a veto player. This is a contestable decision.

${ }^{3}$ For a rare analysis of democratization combining Sub-Saharan Africa and Arab North Africa see Thiriot 2013.
} 
Competitive authoritarian regimes are regimes in which democratic institutions exist on paper, but are subverted by incumbents. ${ }^{4}$ Regular elections take place in all competitive authoritarian regimes. These elections are meaningful in the sense that the opposition does at least stand a theoretical chance of winning. At the same time, however, competitive authoritarian regimes have an autocratic character as the conditions favour the incumbents. According to Levitsky and Way, in competitive authoritarian regimes the incumbents violate at least one of the defining features of democratic regimes (Levitsky and Way 2010, pp. 5-12).

In fully autocratic regimes multiparty elections either do not take place de jure or the opposition parties are de facto excluded from effective participation in the elections. The latter might be due to large-scale falsification of results or severe repression of the opposition (Levitsky and Way 2010, pp. 12-13). This category thus includes what the literature calls hegemonic authoritarian regimes as well as closed autocracies.

The operationalization of these three regime types is explained in detail in appendix I of Levitsky and Way's book, where they code for unfair elections, violation of civil liberties, an uneven playing field, tutelary powers, and voting rights (Levitsky and Way 2010, pp. 365-371). While in an early publication they suggested that "as a rule of thumb, regimes in which presidents are reelected with more than $70 \%$ of the vote can generally be considered noncompetitive" (Levitsky and Way 2002, p. 55), their later operationalization uses an elaborate coding scheme that looks at the electoral process, not election outcomes (see Bogaards 2010). This allows them to identify 35 regimes that became competitive authoritarian in the first half of the 1990s and to track their development up to 2008. Different from their 2002 article, which outlined three paths leading to competitive authoritarianism (decay of a full-blown authoritarian regime, collapse of an authoritarian regime, decay of a democratic regime), the dependent variable in their book is what happened after competitive authoritarian regimes emerged. Thus, they monitor whether competitive authoritarian regimes became full democracies, stable competitive autocracies, or instable competitive autocracies.

To explain the divergent regime trajectories, Levitsky and Way go beyond structural, institutional, and actor-centred explanations, and focus on three independent variables: linkage, leverage, and organizational power. The three explanatory factors can be grouped into international and domestic factors and described as follows:

International explanatory factors:

1. "Linkage (to the West)" refers to the linkage between competitive autocratic regimes and Western states. Linkage can have an economic, political, multilateral, technocratic, or civil society character. Linkage is the most important explanatory factor in accounting for the trajectories of competitive authoritarian regimes. Only linkage can lead to successful democratization. Global linkage scores vary from a low of zero for Tanzania to a high of 0.97 for Guyana. The highest African

\footnotetext{
${ }^{4}$ An illuminating example of the way in which competitive authoritarian regimes manipulate supposedly democratic institutions is Goodfellow's (2014) analysis of parliamentary law making for political purposes rather than policy making in Uganda.
} 
score is 0.38 for Gabon (Levitsky and Way 2010, p. 375). In qualitative terms, linkage is judged low for all African cases of competitive authoritarianism (Levitsky and Way 2010, p. 306).

2. "(Western) leverage" refers to the vulnerability of competitive authoritarian regimes to the external pressure of Western powers to initiate democratization processes. Vulnerability alone rarely results in effective democratization. Leverage is judged high in all African cases of competitive authoritarianism except for Cameroon, because of the so-called "black knight support" from France, and Gabon, because of oil.

National explanatory factor:

3. "Organizational power" refers to the organizational capacity of each government to suppress the democratic opposition. Organizational power can come from three sources: state coercive power, ruling party strength, and state control over the economy. In the coding scheme of organizational power, state coercive power and ruling party strength are measured on two dimensions: scope and cohesion (Levitsky and Way 2010, pp. 376-380). Scores for the various sources of organizational power are added up. No country achieves the theoretical maximum of ten, but Serbia and Zimbabwe come close with a score of eight. In Africa, Benin received the lowest score of zero. In fact, organizational power is the independent variable where African cases show most variation (Levitsky and Way 2010, p. 306).

However, this variation in organizational power among competitive authoritarian regimes in Africa makes no difference for the prospects of democratization, which is determined solely by linkage. The causal logic inherent in Levitsky and Way's theory is brought out most clearly and forcefully by Slater (2011, p. 386), who writes that the "three variables do not so much causally interact as they unfold in a logical sequence". When Western linkage is high, democratization will follow. When linkage is low and organizational power is high, authoritarianism will be the outcome. Under these conditions, then, "Levitsky and Way's argument is essentially monocausal, deterministic, and unidirectional" (Slater 2011, p. 386). When linkage and organizational power are both low, leverage comes into play. This accounts for the difference between stable (low leverage) and unstable (high leverage) authoritarianism. "In other words, Western linkage is the only causal factor theorized to explain the democratization of competitive authoritarian regimes in the post-Cold War era" (Slater 2011, p. 387). When linkage is high, democratization is inevitable and when linkage is low, democratization is unthinkable. Democratization, thus, is always exogenous. "The upshot is that Competitive Authoritarianism-far from teleologically over-predicting democratization - actually under-predicts it" (Slater 2011 , p. 387, emphasis in original). Slater, in contrast, argues that more roads lead to democratization than Levitsky and Way (2010) allow for. In particular, authoritarian weakness and Western leverage are presented as factors that not merely destabilize authoritarianism but can bring about democratization.

In their reply to Slater, Levitsky and Way (2011, p. 388) explain that "the absence of a domestic route to democracy in our study is a product of the particular nature of our cases." By looking exclusively at countries that were competitive authoritarian in 
the early 1990s, almost 20 years after the third wave of democratization had started, they left out the successful early democratizers: those countries that democratized on their own, so to say. Levitsky and Way remain skeptical about the possibilities of democratization when organizational power is low, pointing out that "these cases are characterized not only by weak civil societies and domestic oppositions but also by state and party weakness" (2011, p. 388) and provide unpromising conditions for democratization. A case in point is Ukraine, which they classified as having democratized in their 2010 book, although their theory predicted unstable authoritarianism. One year later they observed that "the Ukraine had already reverted to competitive authoritarianism" (2011, p. 388). ${ }^{5}$ This point is well taken, but the critique of Morse (2012, p. 186) stands that Levitsky and Way do "not provide a theory of democratization within the context of low linkage", which is precisely the situation that Africa finds itself in.

For Africa, Matti (2010, p. 53) finds that in the DRC "postconflict democratization can be largely accounted for by the pressure applied by and incentives attached to foreign aid", aid that was accepted as long as it did not threaten existing patronage networks. Matti's prediction is that the balance of Western aid and Chinese investment will determine whether the country goes into a slightly more democratic or a slightly more authoritarian direction, but that the DRC will remain competitive authoritarian. Similarly, Peiffer and Englebert conclude that "both African and donor dynamics conspire to infuse hybridity with equilibrium qualities likely to inhibit further democratization" (2012, p. 377). On the other hand, recent studies of political parties and elections in Africa have highlighted the role of domestic actors in African politics (Weis 2014; Elischer 2013; Resnick 2013; LeBas 2011; see also Wisemann 1990). ${ }^{6}$

\section{Competitive authoritarianism: what the critics say}

From the book reviews of Levitsky and Way (2010), seven themes emerge: the temporal scope of the argument; the number of regime outcomes; other subtypes of electoral authoritarianism; possible subtypes of competitive authoritarianism; the decisiveness of linkage; the origins of linkage, leverage, and organizational power; and the scope for democracy promotion.

First, the theory is "time- and context-specific" and therefore "may not have much predictive power in the future" (Bours Laborin 2011, p. 255). The starting point is the end of the Cold War and the ending point might well be the emergence of a multipolar world, with an increased role for China as "black knight". Slater (2011, p. 386) has similar concerns and calls this "the question of temporal portability". In their reply,

\footnotetext{
${ }^{5}$ Gilley (2010, p. 165) is alone in his optimistic reading of Levitsky and Way (2010), counting ten countries that "thanks to the rise of effective oppositions, have progressed enough to become borderline democracies". On closer scrutiny, these are cases that Levitsky and Way classify as "unstable authoritarianism"- countries where turnover did not result in democratization but in the continuation of competitive authoritarianism with new, or often not so new, players.

${ }^{6}$ In a similar vein, Vladisavljevic (2014) highlights the role of popular protest in competitive authotarianism.
} 
Levitsky and Way (2011, p. 388) counter that the sensitivity of their theory to "world historical time" is an asset. The question remains, though, how much explanatory power linkage, leverage, and organizational power have for countries that became competitive authoritarian after the 1990s. It is also not clear how much the scope of the theory can be expanded across a broader set of authoritarian regimes (Fenner 2011).

Second, Kubik (2011, p. 663) points out that there are four regime outcomes, not just three. In addition to democratization, unstable competitive authoritarianism, and stable competitive authoritarianism there is also "full authoritarianism", as can be seen in appendix I of their book. Two cases ended up as fully authoritarian regimes: Belarus and Russia. The concept of "full authoritarianism" is specified in the introductory chapter of Levitsky and Way (2010, p. 13) but does not return in the case studies or the conclusion. By consequence, Levitsky and Way fail to look at the process of "autocratization".

Third, in the literature on electoral authoritarianism, which following Schedler (2013) can be broadly conceived as any authoritarian regime with multi-party elections, it is common to distinguish between competitive and hegemonic authoritarianism (see also Bogaards 2013; Bogaards 2014). The difference between the two lies in the chances for success of the opposition: slim but not remote under competitive authoritarianism, negligible under hegemonic authoritarianism. As Morse (2012, p. 187) observes, Levitsky and Way ignore the concept of hegemonic authoritarianism. Cases that they classify as (stable) competitive authoritarian, others would regard as hegemonic authoritarian (e.g. Gabon). On the other side of the political spectrum, Levitsky and Way (2010) may draw the boundary with democracy too tightly, thereby including into the category of competitive authoritarianism cases that are more properly treated as "defective democracies", to use Merkel's term (see Bogaards 2009). For example, Botswana is usually seen as one of the few longstanding liberal democracies in Africa.

Fourth, we may need to unpack the concept of competitive authoritarianism and identify subtypes. Mainwaring (2012, p. 960) describes Venezuela under Chávez as a "participatory, mobilizational, competitive authoritarian regime", different from Fujimori's "demobilizing" competitive authoritarian regime in Peru in the 1990s.

Fifth, does high linkage always result in democratization? Mainwaring (2012, p. 963) observes that "the Venezuelan experience under Chávez runs counter to Levitsky and Way's generally sound argument that it is difficult to consolidate competitive authoritarianism in the Western Hemisphere because of high linkage to the United States. Nicaragua, Ecuador, and Bolivia today are also arguably cases of competitive authoritarianism". Levitsky and Loxton (2013) seek the root of competitive authoritarianism in the Andes region in populism. Because populists are outsiders with little political experience, have an electoral mandate to reform the existing system, and often face hostile institutions dominated by the traditional parties, they tend "to push weak democracies into competitive authoritarianism" (2013, p. 110). Unfortunately, Levitsky and Loxton do not explain why populists are so popular in the Andes and no attempt is made to situate populism in Levitsky and Way's (2010) theory of linkage, leverage, and organizational power. 
Sixth, where do linkage, leverage, and organizational power come from? And are they independent of each other? Van de Walle (2012, p. 172) complains that "Levitsky and Way treat their causal factors as exogenously determined". Tolstrup (2013), in contrast, emphasizes the endogenous nature of linkage, showing how what he calls "gate-keeper elites" have influenced the degree and direction of economic, intergovernmental, technocratic, social, information, and civil society ties in Belarus and Ukraine. Tolstrup's (2013, p. 728) main insight is that linkages are not given and fixed but subject to processes of "linkage-building and linkage-cutting". In a reply, Levitsky and Way (2014) defend their emphasis on structure over choice and play down the relevance of leadership, suggesting it matters only in cases of medium linkage. ${ }^{7}$

In a new line of research, Levitsky and Way $(2012,2013)$ explore the sources of stability of party-based authoritarian regimes. They argue that "the identities, norms, and organizational structures forged during periods of sustained, violent, and ideologically driven conflict are a critical source of cohesion - and durability - in partybased authoritarian regimes" (Levitsky and Way 2012, p. 870, emphasis in original). Hence, revolutionary or liberation parties are expected to remain in power and withstand democratic challenges, at least as long as the original cohort is still at the helm. The argument is illustrated with four cases from Africa, following a most similar research design: Kenya, Mozambique, Zambia, and Zimbabwe. The two parties with origins in violent struggle are still in power (the Zimbabwe African National UnionPatriotic Front and the Mozambique Liberation Front) whereas the two ruling parties without such roots (the Kenya African National Union and the United National Independence Party in Zambia) lost power, demonstrating the vulnerability of patronagebased parties to crisis. Although Levitsky and Way $(2012,2013)$ make no attempt to link this argument to their previous work on (the trajectories of) competitive authoritarianism, their current research on the durability of revolutionary regimes could be seen as deepening our understanding of the origins of organizational (and coercive) power, implicitly answering questions of the type: "Why do some dictators succeed in building effective coercive institutions while others fail"? (Art 2012, p. 369).

Finally, what does Levitsky and Way's structuralist theory imply for attempts to spread democracy around the world? Burnell (2013) criticizes the book for failing to make explicit the policy implications. Using the distinction between linkage and leverage, Burnell associates democratic assistance with the former and democracy promotion with the latter, thereby providing a framework for thinking about the possibilities of strengthening the background conditions for democracy and aiding domestic democratic actors (see also von Soest and Wahman 2015).

\section{Competitive authoritarianism in Africa}

According to Levitsky and Way (2010) there are 14 African countries where competitive autocracies formed in the early 1990s. The continent is generally characterized

\footnotetext{
${ }^{7}$ Though Way's (2012b) analysis of incompetence and political skills suggests a more prominent role for agency.
} 
by a low degree of linkage with the West. This means that democracy is unlikely, irrespective of the vulnerability of a country to Western leverage or the organizational power of the regime. Their boldest claim, according to Fenner (2011, p. 936), is that high-linkage countries "will democratize even when domestic conditions favor authoritarianism". This implies that all authoritarian efforts are, in the end, futile as “even brick houses will collapse where linkage is high" (Fenner 2011, p. 936).

Variation in leverage and organizational power merely helps to predict the stability of competitive authoritarianism. When organizational power is even medium high, the regime is expected to be strong enough to withstand both the domestic opposition and any foreign pressure to democratize that might exist. Only when organizational power is low or medium does leverage make a difference: Low domestic sources of strength coupled with the typically high vulnerability to leverage in Africa are supposed to result in unstable competitive authoritarianism.

As evident in Table 1, 11 of the 14 African cases conformed to the theoretical expectations. The deviant cases are Benin, Mali, and Ghana. Contrary to Levitsky and Way's prediction of competitive authoritarianism, these countries democratized.

Table 1 Trajectories of competitive authoritarian regimes in Africa. (Source: Levitsky and Way (2010, p. 306))

\begin{tabular}{|c|c|c|c|c|c|}
\hline Country & Linkage & $\begin{array}{l}\text { Organizational } \\
\text { power }\end{array}$ & Leverage & Predicted outcome & Actual outcome \\
\hline Benin & Low & Low & High & $\begin{array}{l}\text { Unstable } \\
\text { authoritarianism }\end{array}$ & Democratization \\
\hline Botswana & Low & High & High & $\begin{array}{l}\text { Stable } \\
\text { authoritarianism }\end{array}$ & $\begin{array}{l}\text { Stable } \\
\text { authoritarianism }\end{array}$ \\
\hline Cameroon & Low & Medium & Medium & $\begin{array}{l}\text { Stable } \\
\text { authoritarianism }\end{array}$ & $\begin{array}{l}\text { Stable } \\
\text { authoritarianism }\end{array}$ \\
\hline Gabon & Low & High & Medium & $\begin{array}{l}\text { Stable } \\
\text { authoritarianism }\end{array}$ & $\begin{array}{l}\text { Stable } \\
\text { authoritarianism }\end{array}$ \\
\hline Ghana & Low & Medium & High & $\begin{array}{l}\text { Unstable } \\
\text { authoritarianism }\end{array}$ & Democratization \\
\hline Kenya & Low & Medium & High & $\begin{array}{l}\text { Unstable } \\
\text { authoritarianism }\end{array}$ & $\begin{array}{l}\text { Unstable } \\
\text { authoritarianism }\end{array}$ \\
\hline Madagascar & Low & Low & High & $\begin{array}{l}\text { Unstable } \\
\text { authoritarianism }\end{array}$ & $\begin{array}{l}\text { Unstable } \\
\text { authoritarianism }\end{array}$ \\
\hline Malawi & Low & Low & High & $\begin{array}{l}\text { Unstable } \\
\text { authoritarianism }\end{array}$ & $\begin{array}{l}\text { Unstable } \\
\text { authoritarianism }\end{array}$ \\
\hline Mali & Low & Low & High & $\begin{array}{l}\text { Unstable } \\
\text { authoritarianism }\end{array}$ & Democratization \\
\hline Mozambique & Low & Medium High & High & $\begin{array}{l}\text { Stable } \\
\text { authoritarianism }\end{array}$ & $\begin{array}{l}\text { Stable } \\
\text { authoritarianism }\end{array}$ \\
\hline Senegal & Low & Medium & High & $\begin{array}{l}\text { Unstable } \\
\text { authoritarianism }\end{array}$ & $\begin{array}{l}\text { Unstable } \\
\text { authoritarianism }\end{array}$ \\
\hline Tanzania & Low & Medium High & High & $\begin{array}{l}\text { Stable } \\
\text { authoritarianism }\end{array}$ & $\begin{array}{l}\text { Stable } \\
\text { authoritarianism }\end{array}$ \\
\hline Zambia & Low & Medium Low & High & $\begin{array}{l}\text { Unstable } \\
\text { authoritarianism }\end{array}$ & $\begin{array}{l}\text { Unstable } \\
\text { authoritarianism }\end{array}$ \\
\hline Zimbabwe & Low & High & High & $\begin{array}{l}\text { Stable } \\
\text { authoritarianism }\end{array}$ & $\begin{array}{l}\text { Stable } \\
\text { authoritarianism }\end{array}$ \\
\hline
\end{tabular}


Levitsky and Way (2010, p. 306) downplay the first two as being fragile democracies at best. Ghana's democratization, they admit, "is not explained by our theory" (Levitsky and Way 2010, p. 307). It is important to add that the temporary democratic downfall of Mali in 2012 has little to do with the factors outlined by Levitsky and Way. The military coup of March 2012 was a reaction to the failure of Mali's civilian rulers to contain the conquest of the country's North by a Salafi militia with Algerian and Arabic origins. Interestingly the military coup ushered in the restoration of multiparty democracy. Malian democracy survived the dramatic events of 2012, which indicated that it might not be that fragile after all and thus remains a "deviant democracy" (Seeberg 2014).

In line with recent research that is careful to distinguish between opposition victory and democratization (Cheeseman 2010; Wahman 2014), Levitsky and Way (2010, p. 308) observe that "the African cases experienced more turnover than democratization". This accounts for the high number of cases of unstable competitive authoritarianism. The critical question, as formulated by Wahman (2014, p. 224), is: "Why do some turnovers lead to democratization while others do not?"

\section{Competitive authoritarianism in Africa revisited}

There has been a lively debate about the causes of the so-called color revolutions in some Eastern European and post-Soviet countries, with country and regional experts highlighting the importance of regional diffusion effects, leadership strategy, and the opposition's power to mobilize (Bunce 2011; Way 2008 and 2009). Such debates have been absent in the literature on regime change in Africa. This special issue hopes to stimulate such exchanges through a critical engagement with the role of linkage, leverage, and organizational power in the shaping of regimes and regime trajectories across the continent. Some of the articles collected here focus on the theory, the concept, or measurement issues, while others are empirical studies of selected cases. What all nine contributions share is the desire to work with Levitsky and Way's framework, to deepen our understanding of a particular regime type in post-third wave Africa, to further develop our means for studying this phenomenon, and to assess the prospects of democratization in these cases.

Gabrielle Bardall uses Levitsky and Way's coding scheme in an attempt to verify their classification of African regimes. While in the hard sciences the replication of existing studies is common practice, unfortunately very few social scientists follow this lead. Her findings are sobering: Her team is unable to confirm most of the 14 competitive authoritarian regimes that Levitsky and Way identify and even adds some cases that Levitsky and Way dismiss. Bardall then takes a critical look at the concept and the measurement, before formulating suggestions to improve the empirical study of competitive authoritarian regimes.

Svein Erike Helle provides an in-depth reexamination of Levitsky and Way's concept of the level playing field, one of their main contributions. Helle raises three points: First, the definition does not match the operationalization of the concept. Second, the empirical link between a level playing field and the emergence of competitive authoritarian regimes in Africa proves tenuous. Third, there is a need for 
a more differentiated measurement of the concept. Subsequently, Helle presents a new disaggregated framework and illustrates its empirical validity by applying it to Zambia. He is able to show that over time Zambia's playing field has become more even, an important factor that accounts for the opposition victory in the 2011 Zambian elections.

Christof Hartmann highlights the positive effect of regional organizations on democratization. Going beyond the preoccupation with the African Union (see Fombad 2012), he compares the mandate of all major regional organizations to foster democratic rule and finds that the Economic Community of West African States (ECOWAS) has played an important role in turning Mali, Ghana, and Benin into democratizers. By designing a model of regional linkage and leverage, Hartman adds an important new element to Levitsky and Way's framework.

Will South Africa go the way of Zimbabwe? What explains the different trajectories of these two neighboring countries, both governed by former liberation movements? While some South African scholars already found evidence that South Africa is moving in the direction of a competitive authoritarian regime (De Jager and Meintjes 2013), Southall detects more differences than similarities. ${ }^{8}$ In his view, linkage and leverage have kept the African National Congress (ANC) and thereby South Africa democratic.

Jonathan Hill, Jonathan van Eerd and Jude Kagoro apply Levitsky and Way's framework to a number of additional cases. In doing so, all three contributions question Levitsky and Way's original case selection. Jonathan Hill's discussion of regime developments in Algeria explains how Algeria was able to withstand the Arab Spring and why meaningful democratic reform has not yet taken place (see also Parks 2012 and Volpi 2013). Hill demonstrates the empirical validity of the conceptual toolkit of competitive authoritarianism in a world region where the study of regime change is still in its infancy.

Like Hill, Jonathan van Eerd provides a systematic application of Levitsky and Way's framework to a new empirical case. Van Eerd focuses on Lesotho's first democratic turnover of 2013. Going against the grain, he argues that Lesotho will remain a competitive authoritarian regime due to the country's low linkage with the West and the low organizational power of Lesotho's former incumbents. In addition, van Eerd sheds light on South Africa's unfulfilled potential as a democratic patron in the region.

Jude Kagoro examines the position of the Ugandan military. Although it is difficult to downplay the role of the military in African politics, the literature on competitive authoritarianism has remained largely silent on this topic. Kagoro's article demonstrates that the Ugandan military enjoys extensive links with Uganda's ruling party and plays an important part in keeping President Museveni in power.

In his case study of Tanzania, Alexander Makulilo examines spatial variation in authoritarian stability, going beyond the general focus on the Chama Cha Mapinduzi (CCM) (see Morse 2014). His contribution highlights how linkage, leverage, and especially organizational power are not uniform across the two main parts of the country: mainland Tanzania versus Zanzibar and Pemba. Makulilo thus connects the

\footnotetext{
${ }^{8}$ For a critical account of Namibia's post-independence trajectory, see Melber 2015.
} 
study of competitive authoritarianism to the recent literature on subnational authoritarianism (Gibson 2010). Moreover, his findings would seem to provide additional support for Way's claim (Way 2012a, p. 439) that regional identity can be a source of opposition strength.

Finally, Andrea Cassani and Giovanni Carbonne approach competitive authoritarianism from a new angle. They examine the socioeconomic consequences of competitive authoritarian regimes. Their quantitative study shows that competitive authoritarian regimes outperform full authoritarian regimes. They further demonstrate that full democratization is very likely to have provided even greater benefits to African populations.

\section{Conclusion}

Collectively, these nine original articles make important points that can be grouped under two broad headings: new insights into hybrid regimes in Africa and advances in the study of competitive authoritarianism. However, any such distinction in the end is artificial, as all contributions arguably do both simultaneously. Bardall's critique of the empirical identification of competitive authoritarianism in Africa and Helle's article on the concept and measurement of the level playing field help to delineate competitive authoritarian regimes, deepening our understanding of what makes this type of hybrid regime different from both democracies and more fully autocratic regimes. The contributions by Hartmann and van Eerd emphasize the importance of regional organizations and regional powers, giving prominence to linkage and leverage within Africa, substituting African regional organizations and African regional powers for Western linkage and leverage. ${ }^{9}$ On the other hand, Southall's examination of the countervailing powers of organizational power highlights how the trajectories of similarly situated dominant parties and former liberation movements may be crucially affected by linkage with and leverage by the democratic West. Kagoro's contribution brings to the fore the role of the military in understanding organizational power, while Hill's article reminds us of the intricate interplay of organizational power, linkage, and leverage. Taken together, these articles thus shed new light on the key variables in Levitsky and Way's theory of competitive authoritarianism. Makulilo's analysis of competitive authoritarianism in Tanzania across space and time highlights the territorial dimension and warns us not to generalize from one part of a country to the next. Finally, Cassani and Carbone, taking competitive authoritarianism as an independent variable, show how regime type makes a difference in the lives of African citizens.

At the very least, this special issue should thus have confirmed the added value of the concept and theory of competitive authoritarianism for the study of Africa's hybrid political regimes. But hopefully it has also shown ways in which the concept and measurement of competitive authoritarianism can be refined, suggested new interpretations of linkage, leverage, and organizational power as the variables shaping the trajectory of competitive authoritarian regimes, and added a new dimension

\footnotetext{
${ }^{9}$ For a similar argument, focusing on what they term regional "authoritarian gravity centres", see Kneuer and Demmelhuber 2015.
} 
by asking what these regimes do, not just where they come from and how they developed. In this sense, the contributions have relevance far beyond Africa and should inspire scholars of hybrid regimes researching other parts of the world.

Some questions could still not be addressed in this special issue. First, there are no definitive accounts yet of deviant democracies in Africa. What made democracy succeed in Benin, Ghana, and Mali, despite Levitsky and Way's dire predictions? Second, the scope of the theory will remain unclear until scholars use the concepts of linkage, leverage, and organizational power to study the development of other regime types. In other words, the question whether Levitsky and Way have provided us with a theory of competitive authoritarianism or a much broader theory of regime change and stability as such remains unanswered. Third, there are internal inconsistencies in Levitksy and Way's own oeuvre about the role of leadership and the effects of dominant parties that began as liberation movements. One can only hope that they will integrate their new line of inquiry into their previous work and not abandon the study of competitive authoritarianism. But even if they do, the contributions to this special issue show that a new generation of scholars is ready to assume the task.

\section{References}

Art, David. 2012. What do we know about Authoritarianism after ten years? Comparative Politics 44 (3): $351-371$.

Bejarano, Anna Maria. 2011. Book review of Levitsky and Way (2010). Political Science Quaterly 126 (4): 715-716.

Bogaards, Matthijs. 2009. How to classify hybrid regimes? Defective democracy and electoral authoritarianism. Democratization 16 (2): 399-423.

Bogaards, Matthijs. 2010. Measures of democratization: From degree to type of war. Political Research Quaterly 63 (2): 475-488.

Bogaards, Matthijs. 2013. Reexamining African elections. Journal of Democracy 24 (4): 151-160.

Bogaards, Matthijs. 2014. Multiparty elections in Africa: For better or worse. In Political parties, party systems and democracy in Africa, eds. Renske Doorenspleet and Lia Nijzink, 22-44. Basingstoke: Macmillan.

Bours Laborin, Mario. 2011. Mock democracies: Authoritarian cover-ups. Journal of International Affairs 65 (1): 254-256.

Bunce, Valerie. 2011. Defeating authoritarian leaders in post-communist countries. New York: Cambridge University Press.

Burnell, Peter. 2013. Review article: Promoting democracy. Government and Opposition 48 (2): $265-287$.

Carothers, Thomas. 2002. The end of the transition paradigm. Journal of Democracy 13 (1): 5-21.

Cheeseman, Nic. 2010. African elections as vehicles for change. Journal of Democracy 21 (4): 139-153.

Dahl, Robert A. 1971. Polyarchy. Participation and Opposition. New Haven: Yale University Press.

De Jager, Nicola, and Cara Meintjes. 2013. Winners, losers and the playing field in southern Africa's 'Democratic Darlings': Botswana and South Africa compared. Politikon 40 (2): 233-253.

Diamond, Larry. 2002. Thinking about hybrid regimes. Journal of Democracy 13 (2): 21-35.

Elischer, Sebastian. 2013. Political parties in Africa. Ethnicity and party formation. Cambridge: Cambridge University Press.

Fenner, Sofia. 2011. Book review of Levitsky and Way (2010). Comparative Political Studies 44 (7): 935-939.

Fombad, Charles. 2012. The African Union and democratization. In Routledge handbook of democratization, ed. Jeffrey Haynes, 322-336. London: Routledge.

Gibson, Edward. 2010. Politics in the periphery: An introduction to subnational authoritarianism and democratization in Latin America. Journal of Politics in Latin America 2 (2): 3-12.

Gilley, Bruce. 2010. Democratic triumph, scholarly pessimism. Journal of Democracy 21 (1): 160-167. 
Goodfellow, Tom. 2014. Legal maneuvers and violence: Law making, protest and semi-authortarianism in Uganda. Development and Change 45 (4): 1-24.

Karl, Terry Lynn. 1995. The hybrid regimes of Central America. Journal of Democracy 7 (2): 3-14.

Kneuer, Marianne, and Thomas Demmelhuber. 2015. Gravity centres of authoritarian rule: A conceptual approach. Democratization. doi:10.1080/13510347.2015.1018898.

Kubik, Jan. 2011. Book review of Levitsky and Way (2010). Slavic Review 70 (3): 660-664.

LeBas, Adrienne. 2011. From protest to parties. Oxford: Oxford University Press.

Levitsky, Steven and James Loxton. 2013. Populism and competitive authoritarianism in the Andes. Democratization 20 (1): 107-136.

Levitsky, Steven, and Lucan Way. 2002. The rise of competitive authoritarianism. Journal of Democracy 13 (2): 51-64.

Levitsky, Steven, and Lucan Way. 2010. Competitive authoritarianism. Hybrid regimes after the Cold War. New York: Cambridge University Press.

Levitsky, Steven, and Lucan Way. 2012. Beyond patronage: Violent struggle, ruling party cohesion, and authoritarian durability. Perspectives on Politics 10 (4): 869-889.

Levitsky, Steven, and Lucan Way. 2013. The durability of revolutionary regimes. Journal of Democracy 24 (3): $5-17$.

Levitsky, Steven, and Lucan Way. 2014. Structure vs. choice. Journal of Democracy 25 (4): 151-156.

Mainwaring, Scott. 2012. From representative democracy to participatory competitive authoritarianism: Hugo Chávez and Venezuelan politics. Perspectives on Politics 10 (4): 955-967.

Matti, Stephanie. 2010. The democratic republic of the Congo? Corruption, patronage, and competitive authoritarianism in the DRC. Africa Today 56 (4): 43-61.

Melber, Henning. 2015. Post-liberation democratic authoritarianism: The case of Namibia. Politikon 42 (1): 45-66.

Morse, Yonathan. 2012. The era of electoral authoritarianism. World Politics 64 (1): 161-198.

Morse, Yonathan. 2014. Party matters: The institutional origins of competitive hegemony in Tanzania. Democratization 21 (4): 655-677.

O'Donnell, Guillermo, and Philippe Schmitter. 2013. Transitions from autocratic rule. Tentative conclusions about uncertain outcomes. Washington, D.C.: Woodrow Wilson Center Press.

Parks, Robert. 2012. Algeria and the Arab uprisings. In The Arab Spring: Will it lead to democratic transitions? eds. Clement Henry and Ji-Hyang Jang, 56-71. Basingstoke: Palgrave Macmillan.

Peiffer, Caryn, and Pierre Englebert. 2012. Extraversion, vulnerability to donors, and political liberalization in Africa. African Affairs 111 (444): 355-378.

Resnick, Danielle. 2013. Urban poverty and party populism in African democracies. New York: Cambridge University Press.

Schedler, Andreas. 1998. What is democratic consolidation? Journal of Democracy 9 (2): 91-107.

Schedler, Andreas. 2013. The politics of uncertainty: Sustaining and subverting electoral authoritarianism. Oxford: Oxford University Press.

Seeberg, Michael. 2011. Book review of Levitsky and Way (2010). Democratization 19 (1): 141-155.

Seeberg, Michael. 2014. Mapping deviant democracies. Democratization 41 (4): 634-654.

Slater, Dan. 2011. Book review of Levitsky and Way (2010). Perspectives on Politics 9 (2): 385-388.

Thiriot, Céline. 2013. Des transitions africaines au monde arabe, 1991-2011: Vent de printemps sur les outils de la transitologie. Revue Internationale De Politique Comparée 20 (2): 145-163.

Tolstrup, Jakob. 2013. When can external actors influence democratization? leverage, linkage, and gatekeeper elites. Democratization 20 (4): 716-742.

van de Walle, Nicholas. 2002. Elections without democracy. Journal of Democracy 13 (2): 66-80.

Van de Walle, Nicolas. 2012. Between authoritarianism and democracy. Journal of Democracy 23 (1): 169-173.

Vladisavljevic, Nebojsa. 2014. Competitive authoritarianism, and popular protest: evidence from Serbia under Milosevic. International Political Science Review. doi:10.1177/0192512114535450.

Volpi, Frédéric. 2013. Algeria versus the Arab Spring. Journal of Democracy 24 (3): 104-115.

von Soest, Christian, and Michael Wahman. 2015. Not all dictators are equal: Coups, fraudulent elections, and the selective targeting of democratic sanctions. Journal of Peace Research 52 (1): 17-31.

Wahman, Michael. 2014. Democratization and electoral turnover in Sub-Saharan Africa and beyond. Democratization 21 (2): 220-243.

Way, Lucan. 2008. The real causes of the color revolutions. Journal of Democracy 19 (3): 55-69.

Way, Lucan. 2009. A reply to my critics. Journal of Democracy 20 (1): 90-97. 
Way, Lucan. 2012a. The sources of authoritarian control after the Cold War: East Africa and the former Soviet Union. Post-Soviet Affairs 28 (4): 424-448.

Way, Lucan. 2012b. Dear in headlights: Incompetence and weak authoritarianism after the cold war. Slavic Review 71 (3): 619-646.

Weidmann, Nils. 2011. Book review of Levitsky and Way (2010). Journal of Peace Research 48 (6): 818.

Weis, Toni. 2014. Dominant parties and the private sector in Sub-Saharan Africa: A typology of approaches. Comparative Politics and Governance 8 (3-4): 263-281.

Wisemann, John. 1990. Democracy in black Africa: Survival and revival. USA: Paragon House Publishers. 